\title{
EVALUATION OF THE THORACOABDOMINAL MOBILITY OF OBESE SUBJECTS IN PRE-BARIATRIC SURGERY
}

\author{
Avaliação da mobilidade toracoabdominal dos obesos no pré-operatório de cirurgia bariátrica \\ Ana Paula Limongi Richardelli VELOSO, Karla Garcez CUSMANICH
}

From the Universidade de Taubaté (UNITAU) and Clínica Vida Vale (University of Taubaté (UNITAU) and Vida Vale Clinic), Taubaté, SP, Brazil

HEADINGS - Abdominal circumference. Obesity. Physical therapy specialty. Bariatric surgery.
ABSTRACT - Background: Obesity can affect the thorax, diaphragm, and alterations in respiratory function even if the lungs are within normality. The respiratory compliance is very reduced by the increase in fat mass. Aim: To evaluate the effect of the physical therapeutic respiratory exercises on the thoracoabdominal mobility of obese individuals in pre-bariatric surgery Methods: Cross-sectional and descriptive study, which used the cirtometry (axillary, xiphoid and abdominal) to evaluate the mobility of 74 individuals, 27 men and 47 women, in pre-bariatric surgery, assisted by the team EMAD, after eight weeks of physiotherapy, following a protocol of exercises, reevaluating and compared the measures pre and post intervention. Results: Had positive correlation abdominal mobility in the total volume of all participants $(p=0.010)$ and also for all the measures in the measurement of residual volume in three levels $(p=0.000)$. Comparing genders, in total volume, cirtometry abdominal greater for women $(p=0.015)$ when compared to men and residual volume, significance for either men or women in all measurements $(p=0.000)$. Conclusion: Obese patients that underwent the physiotherapeutic treatment during the preoperative period, had pré respiratory dynamics improved by the increase in the mobility of the chest cavity and by the improvement of respiratory conscience.

\section{Correspondence:}

Ana Paula Limongi Richardelli Veloso

E-mail: anapaulalrveloso@gmail.com

Financial source: none

Conflicts of interest: none

Received for publication: 10/12/2015

Accepted for publication: 14/04/2016

DESCRITORES: Circunferência abdominal. Obesidade. Fisioterapia. Cirurgia Bariátrica.
RESUMO - Racional: A obesidade pode afetar o tórax e o diafragma, determinando alterações na função respiratória, mesmo quando os pulmões se apresentam dentro da normalidade. A complacência respiratória é muito reduzida pelo aumento de massa gordurosa. Objetivo: Avaliar o efeito de exercícios fisioterapêuticos respiratórios sobre a mobilidade torácica de indivíduos obesos no pré-operatório de cirurgia bariátrica. Método: Estudo transversal e descritivo, que utilizou a cirtometria (axilar, xifoide e abdominal) para avaliar a mobilidade de 74 indivíduos, 27 homens e 47 mulheres, em pré-operatório de cirurgia bariátrica, assistidos pela equipe EMAD, após oito semanas de fisioterapia, seguindo um protocolo de exerć́cios, reavaliando e comparado as medidas pré e pós a intervenção. Resultado: Apresentaram correlação positiva a mobilidade abdominal no volume total de todos os participantes $(p=0,010)$ e também para todas as medidas na mensuração do volume residual nos três níveis $(p=0,000)$. Comparando os sexos, no volume total, a cirtometria abdominal maior das mulheres $(p=0,015)$ quando comparada a dos homens e no volume residual, significância tanto para os homens quanto para as mulheres em todas as mensurações $(p=0,000)$. Conclusão: Obesos que se submeteram ao tratamento fisioterapêutico durante o período pré-operatório, tiveram dinâmica respiratória melhorada pelo aumento da mobilidade da caixa torácica e pela melhora da consciência respiratória.
INTRODUCTION

C andidates for bariatric surgery are patients with BMI greater than $40 \mathrm{~kg} /$ $\mathrm{m}^{2}$ or greater than $35 \mathrm{~kg} / \mathrm{m}^{2}$ associated with comorbidities ${ }^{3,7}$. Abdominal surgeries can affect the respiratory musculature by means of different mechanisms, such as pain and the loss of the integrity of the abdominal muscles by incision and neuromuscular blockers for anesthesia, which interfere in the muscle contractility, and contribute to inadequate performance of respiratory muscles after operation ${ }^{4,15}$.

General anesthesia has been cited as an important risk factor for respiratory changes in the postoperative period. May be related to the presence of bronchospasm by trauma to the airway, decreased pulmonary compliance by changing the distensibility of the lungs, reduction of chest expansion, early closing of the airways and ventilation redistribution for the zones, potential for superior pulmonary atelectasis and postoperative hypoxemia ${ }^{8,16}$. The majority of the postoperative complications arise from preoperative causes and some exercises can be made to decrease the chances of complications that end up increasing the hospital stay ${ }^{1,14}$.

In obese the diaphragm is located in upper position, which may decrease functional residual capacity ${ }^{9}$. Obesity typically promotes changes in respiratory 
function, by presenting a large quantity of adipose tissue around the ribcage (decreasing complacency), and also by the elevation of the diaphragm, caused by compression made by abdominal content. These factors lead to decreased functional residual capacity and alter its gaseous exchanges, in virtue of the superficial ventilation ${ }^{2,13}$. The complacency of the respiratory system is very low, because of the increase in mass of the chest wall and limited diaphragmatic excursion ${ }^{17,19}$.

Studies ${ }^{9,17}$ performed in obese not diagnosed with other diseases have suggested that pulmonary and chest wall compliance decrease due to fat deposition in the chest and abdomen, fact that leads to increased elastic retraction and reduced distensibility of extra pulmonary structures. Obesity can affect the thorax, diaphragm, and alterations in respiratory function even if the lungs are within normality ${ }^{22}$. These changes are due to increased respiratory effort and impairment of the gas transport system. The hypertonia in the abdominal muscles, is another symptom associated to obesity, which compromises the respiratory function dependent on the role of the diaphragm ${ }^{6,22}$. For the purposes of respiratory muscle training and development of habit to recovery postoperative pulmonary, some respiratory actions are adopted, among them, the use of inspiratory stimulants. Normally patients are advised to train before operation, in series, some times a day, throughout the pre-operative period. This modality of physical respiratory training is intensified in the moment of admission ${ }^{14,21}$

This study aimed to evaluate, through cirtometry, the effect of respiratory physical therapeutic exercises on the thoracoabdominal mobility of obese individuals in prebariatric surgery.

METHOD

Were selected 74 individuals in the pre-bariatric surgery. All belonged to the group of patients attended at the Vida Vale Clinic, Taubaté, SP, Brazil, which passed by monitoring of multiprofessional team counting with three surgeons, cardiologist, endocrinologist, psychologist, nutritionists and physiotherapy, in preparation for bariatric surgery. All participants signed a free and informed consent. This study with protocol number 1.188.024 was approved by the Ethics in Research.
The only inclusion criterion was being obese in prebariatric surgery and the exclusion with $\mathrm{BMI}<30 \mathrm{~kg} / \mathrm{m}^{2}$.

Cirtometry was used as measurement method and the measurements were performed with the volunteers on foot, in ground.

To start the procedure learning maneuver was made to maximum inspiration and after maximum expiration, measuring the three regions: 1) axillary perimeter with a metric tape passing by axillary cavus; 2 ) xiphoid perimeter, passing on the xiphoid appendix at the level of the $7^{\text {th }}$ costal cartilage; and 3) abdominal perimeter, passing through the umbilicus. Three measurements were carried out by noting the best value (greater difference between measures), maximum inspiration (total lung capacity - TLC) assuming a forced expiration and maximum expiration (residual volume - RV) starting from the deep inspiration.

After the initial assessment the results were recorded on record for each volunteer and all guidelines were carried out, including the purchase of incentive spirometry device. Afterwards, the second session began with the exercise protocol consisted in physiotherapeutic exercises for breathing consciousness, strengthening upper limbs, trunk and aerobic during eight weeks and, after completed this phase, another cirtometry was made for comparing the values. The program consisted of eight sessions of physical therapy once a week, being initially collected vital signs (heart rate, respiratory rate, oxygen saturation, blood pressure and pulmonary auscultation) and then performing the exercises described in Figure 1.

Was orientated to all patients to perform at home a series of 10 repetitions of Respiron ${ }^{\circledR}$ at least once a day, plus diaphragmatic breathing and a series of 10 repetitions whenever remembered during the day.

\section{Statistical analysis}

The data were analyzed using the Stata version 11.0 and treated with descriptive analysis (mean and standard deviation) and inferential. The Shapiro-Wilk test was used to verify the normality of the data and homogeneity of variance. For the comparison between initial and final measurements obtained by cirtometry, was used the paired t-test. The level of significance adopted was $5 \%(p<0,05)$.

\begin{tabular}{|c|c|c|}
\hline Exercise & Patient position & Implementation \\
\hline $\begin{array}{l}\text { Diaphragmatic breathing with } \\
\text { ankle weight of } 4 \mathrm{~kg} \text { on abdomen }\end{array}$ & $\begin{array}{l}\text { Lying on the stretcher, positioning the feet and hip at } \\
90^{\circ} \text { with the aid of a therapeutic ball under the knees, } \\
\text { putting the ankle weight below the xiphoid process }\end{array}$ & $\begin{array}{l}1 \text { series of } 10 \text { repetitions; perform inspiration by the nose, } \\
\text { expanding the abdomen without moving the thorax and } \\
\text { expire by the mouth by deflating the lungs and abdomen }\end{array}$ \\
\hline $\begin{array}{l}\text { Diaphragmatic breathing associated } \\
\text { with the elevation of the upper } \\
\text { limbs with halter of } 1 \mathrm{~kg} \text { or } 2 \mathrm{~kg}\end{array}$ & $\begin{array}{l}\text { Lying on the stretcher, positioning the feet and hip at } \\
90^{\circ} \text { with the aid of a therapeutic ball under the knees }\end{array}$ & $\begin{array}{l}1 \text { series of } 10 \text { repetitions; perform inspiration by the nose, } \\
\text { expanding the abdomen without moving the thorax lifting } \\
\text { the arms, to expire by the mouth empty the lungs and } \\
\text { abdomen by lowering the lift arms }\end{array}$ \\
\hline $\begin{array}{l}\text { Fractionated in } 3 \text { times inspiration } \\
\text { with elevation of the upper limbs }\end{array}$ & $\begin{array}{l}\text { Lying on the stretcher, positioning the feet and hip to } \\
90^{\circ} \text {, with the aid of a therapeutic ball under the knees }\end{array}$ & $\begin{array}{l}1 \text { series of } 10 \text { repetitions; inspiration by nasal, smooth, and } \\
\text { with small apneas, in three times, and expiration continues } \\
\text { by mouth }\end{array}$ \\
\hline Abdominal & $\begin{array}{l}\text { Lying on the stretcher, positioning the feet and hip to } \\
90^{\circ} \text {, with the aid of a therapeutic ball under the knees }\end{array}$ & $\begin{array}{l}1 \text { series of } 10 \text { repetitions; expire flexing the trunk until } \\
\text { forming an approximate angle of } 45^{\circ} \text { and return inspired }\end{array}$ \\
\hline Bridge & $\begin{array}{l}\text { Lying on the stretcher, positioning the feet and hip to } \\
90^{\circ} \text {, with the aid of a therapeutic ball under the knees }\end{array}$ & $\begin{array}{l}1 \text { series of } 10 \text { repetitions; raise the hip slowly expiring, and } \\
\text { return inspired }\end{array}$ \\
\hline Flexion of arm in ball & $\begin{array}{l}\text { Standing with the ball against the wall, therapeutics in } \\
\text { breast height }\end{array}$ & $\begin{array}{l}1 \text { series of } 10 \text { repetitions; supporting the hands on the ball, } \\
\text { flex the elbows expiring, stretch the elbows inspired }\end{array}$ \\
\hline Abduction diagonal with teratubo & $\begin{array}{l}\text { On foot, with their feet slightly apart, in front of the } \\
\text { mirror (visual feedback) }\end{array}$ & $\begin{array}{l}1 \text { series of } 10 \text { repetitions; a hand fixed in the hip region and } \\
\text { the other pulls the diagonal tube during expiration. }\end{array}$ \\
\hline Respiron ${ }^{\circledR}$ & $\begin{array}{l}\text { Seated with feet on the floor, in front of the Mirror (for } \\
\text { visual feedback) }\end{array}$ & 1 series of 10 repetitions \\
\hline Aerobic exercise & Treadmill or cycle ergometer (seated). & $\begin{array}{l}\text { With } 60-70 \% \text { of the submaximal heart rate. With heating } \\
\text { and falloffs of } 1 \mathrm{~min} \text {. }\end{array}$ \\
\hline
\end{tabular}

FIGURE 1 - Exercise protocol 
RESULTS

\section{Participants profile}

Seventy-four volunteers between $17-70$ years of age were enrolled, with an overall mean of $37.4+/-11.1$ years; 47 were women with a mean of $37.9+/-11.2$ years; and 27 men with average of $37.1( \pm 11.0)$.

The general mean BMI was $41.7+/-4.8 \mathrm{~kg} / \mathrm{m}^{2}$ with variation of $34.1-57.1 \mathrm{~kg} / \mathrm{m}^{2}$. Regarding the classification of obesity according to the BMI, the majority (56.2\%) was classified as grade III; $42.5 \%$ degree II; and $1.3 \%$ grade I.

The distribution of BMI according to gender showed that the category most prevalent among women was obesity II (53.2\%) and among men the obesity III (76.9\%).

\section{Thoracoabdominal mobility - total volume}

The values found are described in Table 1. There was no significant difference in axillary and xiphoid mobility among measurements obtained before and after the application of the exercises. Already the abdominal mobility was significantly higher in comparison to the obtained before the exercises.

TABLE 1 - Thoracoabdominal mobility and total volume evaluation values in pre- and post-respiratory therapy

\begin{tabular}{|l|c|c|c|}
\multicolumn{1}{|c}{$\begin{array}{c}\text { Mobility }(\mathrm{cm}) \\
\text { Total volume }\end{array}$} & Initial & End & $\mathrm{p}$ \\
\hline Axillary & $120,3 \pm 10,5$ & $119,7 \pm 10,1$ & 0.072 \\
\hline Xiphoid & $113,6 \pm 10,1$ & $113,9 \pm 10,0$ & 0.844 \\
\hline Abdominal & $123,0 \pm 12,3$ & $124,3 \pm 11,8$ & $0.010^{*}$ \\
\hline
\end{tabular}

The data are expressed in mean \pm standard deviation, ${ }^{*}$ statistical significance $(p<0.05)$

Thoracoabdominal mobility and total volume evaluation values in pre- and post-respiratory therapy showed a positive correlation only for the abdominal mobility $(p=0.010)$. As to gender, it was observed greater significance for abdominal cirtometry in women when compared to men (Table 2).

TABLE 2 - Thoracoabdominal mobility and total volume evaluation values according to gender in pre- and post-respiratory therapy

\begin{tabular}{c|c|c|c|c|c|c|} 
Mobility $(\mathrm{cm})$ & \multicolumn{2}{c}{ Initial } & \multicolumn{2}{c}{ End } & \multicolumn{2}{c|}{ PV Value } \\
\cline { 2 - 7 } Total Volume & Male & Female & Male & Female & Male & Female \\
\hline Axillary & $129,8 \pm 7,5$ & $114,8 \pm 7,6$ & $128,7 \pm 7,6$ & $114,4 \pm 7,2$ & $0,048^{*}$ & 0,365 \\
\hline Xiphoid & $121,7 \pm 7,7$ & $109,0 \pm 8,3$ & $121,9 \pm 7,3$ & $109,2 \pm 8,2$ & 0.706 & 0,890 \\
\hline Abdominal & $133,0 \pm 11,0$ & $117,3 \pm 9,0$ & $134,3 \pm 11,0$ & $119,1 \pm 8,8$ & 0.525 & $0,015^{*}$
\end{tabular}

The data are expressed in mean \pm standard deviation, ${ }^{*}$ statistical significance $(p<0.05)$.

Thoracoabdominal mobility - residual volume

The values found are described in Table 3. The axillary, xiphoid and abdominal postoperative mobility after physical therapy were significantly higher in comparison to the measured initially. In all measures there was reduction of cirtometry.

TABLE 3 - Thoracoabdominal mobility and residual volume evaluation values in pre- and post-respiratory therapy

\begin{tabular}{|c|c|c|c|}
\hline $\begin{array}{c}\text { Mobility (cm) } \\
\text { Residual volume }\end{array}$ & Initial & End & $p$ Value \\
\hline Axillary & $117,3 \pm 10,5$ & $115,0 \pm 10,3$ & $0.000 *$ \\
\hline Xiphoid & $112,4 \pm 10,2$ & $109,4 \pm 9,8$ & $0.000^{*}$ \\
\hline Abdominal & $124,1 \pm 12,2$ & $118,9 \pm 11,9$ & $0.000^{*}$ \\
\hline
\end{tabular}

The data are expressed in mean \pm standard deviation, ${ }^{*}$ statistical significance $(p<0,05)$.

Figure 2 shows the dispersion diagram of the data of the thoracoabdominal mobility and residual volume before and after respiratory physiotherapy. The values found showed positive correlation for all measures $(p=0.000)$.

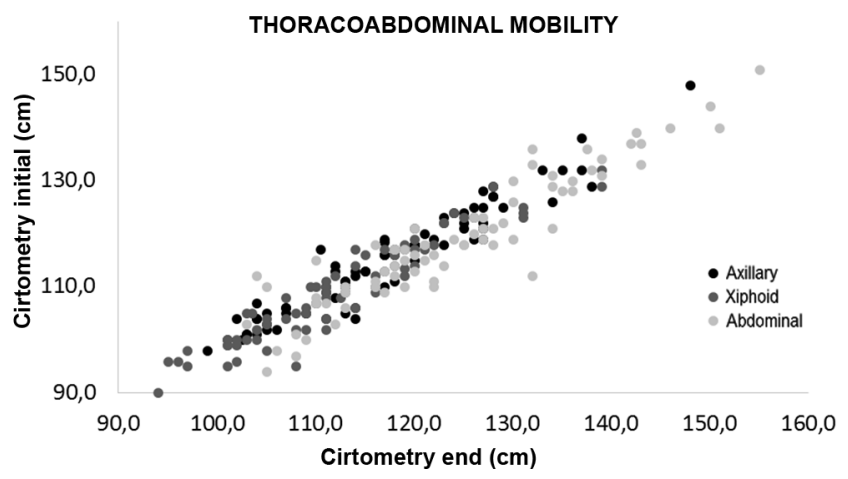

FIGURE 2 - Dispersal diagram of the thoracoabdominal mobility and residual volume

Table 4 demonstrates the mobility regarding gender, and can be observed significance to both men and women in all measurements.

TABLE 4 - Thoracoabdominal mobility and residual volume values according to gender in the pre- and postrespiratory physiotherapy

\begin{tabular}{c|c|c|c|c|c|c|} 
Mobility $(\mathrm{cm})$ & \multicolumn{2}{c}{ Initial } & \multicolumn{2}{c}{ End } & \multicolumn{2}{c|}{$\mathrm{p}$} \\
\cline { 2 - 7 } Total volume & Male & Female & Male & Female & Male & Female \\
\hline Axillary & $126.7 \pm 7.6$ & $111.9 \pm 7.7$ & $123.8 \pm 8.7$ & $109.9 \pm 7.3$ & $0.000^{*}$ & $0.000^{*}$ \\
\hline Xiphoid & $120.1 \pm 7.8$ & $107.9 \pm 8.7$ & $117.4 \pm 7.1$ & $104.8 \pm 8.1$ & $0.000^{*}$ & $0.000^{*}$ \\
\hline Abdominal & $133.8 \pm 10.8$ & $118.5 \pm 9.1$ & $127.9 \pm 11.3$ & $113.7 \pm 8.9$ & $0.000^{*}$ & $0.000^{*}$ \\
\hline
\end{tabular}

The data are expressed in mean \pm standard deviation; ${ }^{*}$ statistical significance $(p<0)$.

\section{DISCUSSION}

Several studies confirm that obesity has a series of different corruptive effects on respiratory function and may be total factor capable of potentiating the development of pulmonary complications.

In obesity, alterations in respiratory function more frequently found are the reduction of expiratory reserve volume and the functional residual capacity, because of the changes in chest wall mechanics, decreasing total respiratory compliance, of the pulmonary volume, reduction in residual volume and its relation with the total lung capacity ${ }^{22}$.

Forti et al ${ }^{10}$ mentioned that the bariatric surgery may lead to changes in the respiratory mechanics and pulmonary function. Thus it is of great importance to achieve adequate respiratory evaluation, both at the pre- and postoperative period, with views on the actuation of respiratory therapy in the prevention and rehabilitation of these patients. As already known, surgical incision in the abdomen and ribcage, can affect the integrity of the respiratory muscles directly affecting its function. The weakening of the respiratory muscles after operation can lead to postoperative complications impairing respiratory function and increase the hospital stay $^{12}$. For these reasons, this paper aimed to minimize these respiratory complications.

These results showed that the measures have improved significantly after the implementation of the exercise protocol. However, one of the main findings was that none of the patients assisted had respiratory complication after surgery.

Paulin et al. ${ }^{18}$ performed a study with 15 patients showing that exercises directed to the increase the mobility of the chest cavity improves chest expansion, the quality of life and the submaximal exercise capacity. As mentioned above, it was evidenced here that exercises directed to the respiratory musculature not only have been able to increase 
the mobility and expandability, as also the consciousness, improving respiratory implementation of diaphragmatic muscles, increasing the thoracoabdominal mobility; this was more evident in the abdominal region, when compared to the axillary and subxiphoid in both genders, mainly in the cirtometry measurement of residual volume.

One study performed in 2011 found the efficacy of pulmonary rehabilitation program to promote significant alterations in respiratory mechanics of 20 obese women, indicating an improvement of thoracic mobility ${ }^{20}$, similar to the present study; however, here were evaluated women and men and also compared the values between the genders.

Results obtained with this treatment program have a relation with the result presented in the study with obese patients of Costa et al. ${ }^{5}$, where it was concluded that respiratory retraining functional applied to seven patients, promoted changes in respiratory mechanics, more properly the thoracoabdominal mechanics. The amplitude levels to axillary and abdominal ones, suggested that these individuals may have their pulmonary function altered through the functional respiratory retraining. These changes promoted inspiratory muscle strength and increased abdominal mobility preventing complications.

The physiotherapeutic treatment has important role during the pre- and postoperative period in the bariatric surgery ${ }^{10,11}$. It is a consensus that the physiotherapeutic treatment during the preoperative period, when indicated as an adjuvant for surgical preparation, represents an important tool in the reduction of complications related to extubation difficulties and atelectasis, among others.

It is expected that the increase in respiratory conscience, in addition to providing the best conditions for which the patients face the operation, can also be useful in the early recovery in the postoperative period.

No papers were found correlating the deficit of respiratory conscience, justifying the muscle strength and mobility found in the great majority of obese.

The exercise program addressed in this study, aiming at the increase in the mobility of the chest cavity, improved it in all levels, proven by values obtained on cirtometry. This can represent one more important tool in the approach of pulmonary rehabilitation, aiming a better quality of life and, in this case, the reduction of postoperative complications favoring shorter hospitalization time, and it's known benefits.

\section{CONCLUSION}

Obese patients that underwent the physiotherapeutic treatment during the preoperative period, had respiratory dynamics improved by the increase in the mobility of the chest cavity, and also by the improvement on respiratory conscience.

\section{REFERENCES}

1. ArcêncioL, SouzaMDD, Bortolin BS, FernandesACM, RodriguesAJ, Evora PR B. Cuidados pré e pós-operatórios em cirurgia cardiotorácica: uma abordagem fisioterapêutica. Rev Bras Cir Cardiovasc, 2008;23(3):400-10.
2. Baltieri L, Santos LA, Rasera I Jr, Montebelo MI, Pazzianotto-Forti EM. Use of positive pressure in the bariatric surgery and effects on pulmonary function and prevalence of atelectasis: randomized and blinded clinical trial. ABCD, arq. bras. cir. dig 2014;27(1):26-30.

3. Casali CCC, Pereira APM, Martinez JAB, Souza HCD, Gastaldi AC. Effects of inspiratory muscle training on muscular and pulmonary function after bariatric surgery in obese patients. Obes Surg. 2011;21(9):1389-1394.

4. CostaD,FortiEMP, Barbalho-MoulimMC.Estudodosvolumespulmonares eda mobilidadetóracoabdominal deportadoras deobesidademórbida, submetidas à cirurgia bariátrica, tratadas com duas diferentes técnicas de fisioterapia. Rev Bras Fisio, São Carlos, 2009;13(4):294-300.

5. Costa D, Sampaio LMM, Lorenzzo VAP, Jamami M, Damaso AR. Avaliação da força muscular respiratória e amplitudes torácicas e abdominais após a RFR em indivíduos obesos. Revista Latino-americana de Enfermagem 2003;11(2):156-60.

6. Cruz MDSL, Fernandes PR, Sonehara E, Reis VM, Policarpo FB, Fernandes FilhoJ.Efeitos deterapêuticas respiratóriaseactividadefísica nas pressões respiratóriasmáximas demulheresobesas. Motricidade2010;6(2):15-21.

7. FandiñoJ,BenchimolAK, CoutinhoWF,AppolinárioJC.Cirurgiabariátrica: aspectos clínico-cirúrgicos e psiquiátricos. Revista de psiquiatria, 2004;26(1):47-51.

8. Filho AAA. Avaliação da ventilometria e espirometria no pré e pósoperatório de pacientes submetidos à cirurgia de hipertensão portal. [dissertação]. São Cristóvão: Universidade Federal de Sergipe 2007.

9. Fonseca-JuniorSJ,SáCGADB, RodriguesPAF, OliveiraAJ,Fernandes-Filho J. Physical exercise and morbid obesity: a systematic review. $A B C D$, arq. bras. cir. dig 2013;26:67-73.

10. Forti EMP, Ike D, Rodrigues N, Ferreira L, Costa D. Estudo da mobilidade torácica de pacientes portadoras de obesidade mórbida, submetidas à gastroplastia

11. GastaldiAC,MagalhãesCMB,BaraúnaMA,SilvaEMC,SouzaHCD.Benefícios da cinesioterapia respiratória no pós-operatório de colecistectomia laparoscópica. Revista Brasileira de Fisioterapia 2008; 12(2):100-6.

12. Guedes GP, Barbosa YRA, Holanda G. Correlação entre força muscular respiratória e tempo de internação pós-operatório. Fisioterapia em movimento 2009;22(4) 605-614.

13. Lehmkuhl E, Neves FM, Panizzi EA, Pamplona CMA, Kerkoski EA. Mobilidade torácica avaliada em diferentes regiões através da técnica de cirtometria em indivíduos saudáveis. Anais do IX Encontro Latino Americano de Iniciação Científica e V Encontro Latino Americano de Pós-Graduação da Universidade do Vale da Paraíba 2007.

14. Llorens J, Rovira L, Ballester M, Moreno J, Hernandez-Laforet J, Santonja F-J, Cassinello N, Ortega J. Preoperative inspiratory muscular training to preventpostoperativehypoxemiainmorbidlyobesepatientsundergoing laparoscopic bariatricsurgery. Arandomized clinical trial.Obesity Surgery 2015; 25(6):1003-1009.

15. Mans CM, Reeve JC, Elkins MR. Postoperative outcomes following preoperativeinspiratorymuscletraininginpatientsundergoing cardiothoracic or upper abdominal surgery: a systematic review and meta analysis. Clinical Rehabilitation 2015;29(5):426-438.

16. Matos CJO, Neto JB, Melo VA, Miranda CBA. Influência da frequência respiratória sobre os gases sanguíneos arteriais no pós-operatório imediatodelaparotomiaexploradoraportraumaabdominal.ASSOBRAFIR Ciência 2013:4(2):53-63.

17. Naimark A, Chernaiak R, Compliance of the respiratory system and its components in health and obesity. Journal Applied Physiology 1960.

18. Paulin $E$, Brunetto AF, Carvalho CRF. Efeitos de programa de exercícios físicos direcionado ao aumento da mobilidade torácica em pacientes portadoresdedoençapulmonarobstrutivacrônica.Jornal dePneumologia São Paulo 2003;29(5):287-94.

19. Rasslan Z, Stirbulov CACL, Junior RS. Função pulmonar e obesidade. Revista Brasileira Clinica Medica 2009:7:36-39.

20. Sonehara E, Cruz MDSL, Fernandes PR, Policarpo F, Filho JF. Efeitos de um programa de reabilitação pulmonar sobre a mecânica respiratória e qualidade de vida de mulheres obesas. Fisioterapia e movimento. Curitiba 2011;24(1):13-21.

21. Trevisan ME, Soares JC, Rondinei TZ. Efeitos de duas técnicas de incentivo respiratório na mobilidade tóraco abdominal após cirurgia abdominal alta. Fisioterapia e Pesquisa, São Paulo, 2010;17(4):322-6.

22. Wrzesinski A, Correia JM, Fernandes TMB, Monteiro LF, Trevisol FS, Nascimento RRD Complications requiring hospital management after bariatric surgery. ABCD, arq. bras. cir. dig 2015; 28:3-6. 